\title{
Mutational Analysis of Mucopolysaccharidosis in Iranian Patients
}

\author{
Seyed Hoseinali Saberi ${ }^{1,2}$, Shahla Farshidi ${ }^{3}$, Behnam Kamalidehghan ${ }^{4}$, Roshanak Jazayeri (iD ${ }^{5,}{ }^{*}$ and \\ Massoud Houshmand ${ }^{1, * *}$ \\ ${ }^{1}$ Department of Medical Genetics, National Institute of Genetic Engineering and Biotechnology, Tehran, Iran \\ ${ }^{2}$ Medical-Genetic Counseling Center, Alborz Welfare Organization, Karaj, Iran \\ ${ }^{3}$ Prevention of Disability Department, Iran Welfare Organization, Tehran, Iran \\ ${ }^{4}$ Medical Genetics Department, Faculty of Medicine, Jiroft University of Medical Sciences, Jiroft, Kerman, Iran \\ ${ }^{5}$ Non-Communicable Diseases Research Center, Alborz University of Medical Sciences, Karaj, Iran \\ "Corresponding author: Non-Communicable Diseases Research Center, Alborz University of Medical Sciences, Karaj, Iran. Email: roshanakjazayeri@gmail.com

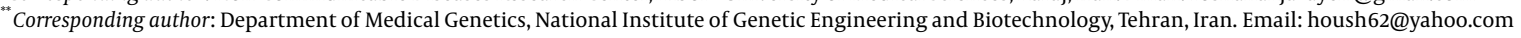

Received 2020 May 19; Revised 2020 June 14; Accepted 2020 July 05.

\begin{abstract}
Mucopolysaccharidosis (MPS) is a rare and heterogeneous metabolic disorder with wide phenotypic distributions throughout the world. This study aimed to determine the genetic polymorphisms, contributing to the most common types of MPS in 19 unrelated Iranian patients. The sequence of the coding region and exon-intron boundaries of the MPS genes were analyzed by Sanger sequencing method. We used the biochemical and clinical characteristics of MPS subjects for genetic analysis. A novel IDUA variant (c.99T $>C$, p.H33H), a novel nonsense change (c.514C > T, p.R172*) in exon 5 of IDS gene, c.74G > A (p. p.R24H) in SGSH gene, and three variants including (c.607C > T (p.R203*), c.259G >C (p.A87P), and c.683G>A (p.R228Q)) in NAGLU (n-acetyl-alpha-glucosaminidase) were predicted as novel pathogenic mutations. In conclusion, this study broadened genotypic spectrum of Iranian MPS patients, facilitating the definition of disease-associated mutations, which help to provide a more effective approach in MPS carrier detection.
\end{abstract}

Keywords: Mucopolysaccharidosis, Mutation Screening, Iran, Genetic Counseling, Sanger Sequencing

\section{Background}

Mucopolysaccharidosis (MPS) is a set of inborn metabolic errors caused by an absence of specific lysosomal enzymes involved in glycosaminoglycan (GAG) catabolism (1). This metabolic block resulted in the GAGs accumulation in various organs, leading to progressive and multisystemic features (2). Based on the impairment of 11 involved enzymes, nine various clinical types and numerous subtypes of MPS have been identified (3). The subdivisions of MPS include Hurler Disease (MPS I), Hunter Syndrome (MPS II), Sanfilippo Syndrome (MPS III), Morquio Syndrome (MPS IV), Maroteaux Lamy Syndrome (MPS VI), Sly Syndrome (MPS VII), and hyaluronidase deficiency (MPS IX) (4).

It is very important to develop the genotypic catalog of specific disorders for a population. In this respect, there is inadequate research based on a limited number of cases in Iran. Therefore, the present study aimed to measure the rate of mutation and compare the data to the studies conducted in neighboring countries so as to identify the status of MPS disease in the Iranian population. Despite important information provided by genetic testing, there are limitations in this regard. Identification of common mutations prevents the need for next generation sequencing (NGS) based tests in MPS candidate patients. This results in lower diagnostic costs for patients and can be identified and categorized at a very low cost, and appropriate therapies can be considered.

\section{Objectives}

In this study, we examined the clinical and biochemical features and genetic analysis of 19 Iranian patients with MPS to identify novel MPS-associated mutations.

\section{Methods}

\subsection{Ethical Statement}

The sample included a total of 19MPS patients referred to the Taban Health Care and Diabetes Clinic (THCDC) from 2009 to 2015 . The present study was approved by the Ethical Committee of National Institute of Genetic Engineering and Biotechnology (NIGEB) (IR.NIGEB.EC.1397.8.23.C), 
Tehran, Iran. Informed consent was obtained from patients. The clinical characteristics of MPS patients were summarized in Table 1.

\subsection{DNA Extraction and Polymerase Chain Reaction (PCR)}

Genomic DNA was extracted using PrimePrep Genomic DNA extraction kit (GeNet Bio) from peripheral blood samples of MPS patients, collected in tubes containing ethylenediaminetetraacetic acid (EDTA) in a final volume of $2 \mathrm{~mL}$. Briefly, the PCR reaction was carried out in a total volume of $25 \mu \mathrm{L}$ containing 50 ng of DNA, $2.5 \mu \mathrm{L}$ of $10 \times$ PCR buffer, $0.1 \mathrm{mM}$ of each dNTP, $1 \mathrm{mM}$ of $\mathrm{MgCl}_{2}, 0.1 \mu \mathrm{M}$ of each primer, and 0.3 units of Taq polymerase enzyme (CinnaGen, Iran) using a thermocycler (Eppendorf, Hamburg). The DNA was denatured at $94^{\circ} \mathrm{C}$ for $5 \mathrm{~min}$, followed by $35 \mathrm{cy}$ cles of denaturation at $94^{\circ} \mathrm{C}$ for $1 \mathrm{~min}$. The annealing temperature was based on the temperature $\left({ }^{\circ} \mathrm{C}\right)$ value of each primer set (Table 2). The extension temperature was at $72^{\circ} \mathrm{C}$ for $1 \mathrm{~min}$, with final extension at $72^{\circ} \mathrm{C}$ for $10 \mathrm{~min}$.

\subsection{Sequencing Analysis}

The double-stranded DNA of PCR products from MPS patients was examined using an automated ABI sequencing machine (Applied Biosystems 3100, Kavosh Fanavaran Kawsar Company, Tehran, Iran). The DNA sequences were confirmed for any nucleotide variation and then analyzed using Finch TV software (http://www.geospiza.com/finchtv/).

\subsection{In Silico Analysis of the Variants}

The impact of novel mutations was verified through Human Gene Mutation Database (HGMD). In order to predict the functional effects of novel variations, the sequence changes were evaluated using in silico prediction algorithms SIFT (5), polyphen (6), and I-Mutant 2.0 (http://folding.biofold.org/i-mutant/i-mutant2.o.html).

\section{Results}

\subsection{Epidemiological and Clinical Data}

In this study, 19 unrelated Iranian MPS patients were affected by MPS I(31\%), MPS II (10\%), MPS IIIA(31\%), and MPS IIIB (26\%) (Table 1).

\subsection{Sequence Analysis}

All the coding exons and intronic boundary regions of the IDUA, IDS, SGSH, and NAGLU genes were assessed by polymerase chain reaction (PCR) in all patients. The list of primers used in this study was presented in Table 2. Direct sequencing of the PCR products showed 16 variants in these genes, among which two nonsense and three missense alterations had been reported in the disease databases previously and two variants were present in the local population database (http://www.iranome.ir) (Table 3).

Except the mentioned variants, remaining variants were not found in the disease databases (Clin Var, OMIM, HGMD, and literature in PubMed till to Jul 29, 2019). Six variants were predicted as disease-causing by Mutation Taster.

\subsection{Amino Acid Substitutions}

Among the cases, six patients had single base-pair substitutions in IDUA gene, five of these variants were detected in exon 1, and a single base pair substitution (c.1205G $>$ A) was detected in exon 9 of one sample. Of the five mutations identified in the IDUA gene, three mutations were the missense type leading to a change in the amino acid sequence, one mutation was the nonsens type that leads to creation of stop codon, and one mutation was the silent type.

We found a single base pair substitution (c.514C $>$ T) in exon 5 of IDS gene in one sample. This mutation is of the nonsense type and leads to the formation stop codons. In addition, four single base-pair substitutions in NAGLU gene were detected in five samples, including a single basepair substitution (c.2209C $>A$ ) in exon 6 of two samples, two single base-pair substitution (c.607c $>$ T and c.683G $>A$ ) in exon 3 of two samples, and a single base-pair substitution (c.259G $>$ C) in exon 1 of one sample. Of these four mutations, three were missense mutations, and one was nonsense mutation. Moreover, our data showed five single base-pair substitutions in SGSH gene in 6 samples, including a single base pair-substitution (c.74G $>A$ ) in exon 1 of one sample, a single base-pair substitution (c.456G $>$ A) in exon 3 of one sample, and two single base-pair substitution (c.364G>A and c.456G>A) were found in two and one of our samples, respectively.

Of these five mutations, four were missense mutations, and one was silent mutation that does not alter the amino acid sequence (type of mutations was summarized in Table 3).

\section{Discussion}

MPS is a group of hereditary, rare, and incurable 'lysosomal storage diseases' (7). It is estimated that 1 in 25,000 newborn children will have some type of the MPS in the United States in 2013 (8). MPS demonstrates remarkable genotypic heterogeneity, explaining the association of genotype-phenotype variability $(9,10)$. The present study indicated clinical and molecular features of 19 patients 


\begin{tabular}{|c|c|c|c|c|c|c|c|c|c|c|}
\hline Patients & MSP Type & Sex & PCM & Clinical Feature & Main Symptom & Face Abnormality & $\begin{array}{l}\text { Biochemical Urine GAG } \\
\text { Accumulation Detected }\end{array}$ & MR & Cardiac Manifestations & Deafness \\
\hline 1 & MSP I & M & + & $\begin{array}{l}\text { Hepatospelnomegaly, } \\
\text { spinal cord curvature }\end{array}$ & $\begin{array}{l}\text { Sever NDD, cloudy cornea, } \\
\text { hearing loss }\end{array}$ & $\begin{array}{l}\text { Coarse face, irregular's } \\
\text { dental, gum hyperplasia, } \\
\text { corneal opacity }\end{array}$ & $\mathrm{DS}>\mathrm{HS}$ & + & MIAI & BT \\
\hline 2 & MSP I & $\mathrm{F}$ & + & CVs & \# & \# & \# & \# & \# & \# \\
\hline 3 & MSP I & $\mathrm{M}$ & + & $\begin{array}{l}\text { Skeletal deformity, stiff } \\
\text { joint, respiratory } \\
\text { infection, claw hand }\end{array}$ & $\begin{array}{l}\text { Deafness, cloudy cornea, } \\
\text { dolichocephalic, CHD, } \\
\text { moderate NDD }\end{array}$ & $\begin{array}{l}\text { gum hyperplasia, cloudy } \\
\text { cornea Coarse face, }\end{array}$ & $\mathrm{DS}>\mathrm{HS}$ & + & MI AS & Mixed \\
\hline 4 & MSP I & $\mathrm{F}$ & + & $\begin{array}{l}\text { Umbilical hernia, } \\
\text { gargoyles, sever } \\
\text { Hepatomegaly, mild } \\
\text { splenomegaly }\end{array}$ & $\begin{array}{l}\text { cloudy cornea 1 year, } \\
\text { deafness 2years }\end{array}$ & $\begin{array}{l}\text { Mild coarse face, } \\
\text { irregular's dental }\end{array}$ & $\mathrm{DS}, \mathrm{HS}$ & + & MS & BT \\
\hline 5 & MSP I & M & + & $\begin{array}{l}\text { Short stature, claw hand, } \\
\text { dysostosis multiplex }\end{array}$ & $\begin{array}{l}\text { Macrocephaly, } \\
\text { viceromegaly, }\end{array}$ & $\begin{array}{l}\text { cloudy cornea, Coarse } \\
\text { face, }\end{array}$ & $\mathrm{DS}>\mathrm{HS}$ & + & MI & Mixed \\
\hline 6 & MSP I & F & + & $\begin{array}{l}\text { Seizure, hepatomegaly, } \\
\text { short stature }\end{array}$ & $\begin{array}{l}\text { Macrocephal, ombelical } \\
\text { hernia }\end{array}$ & $\begin{array}{l}\text { Facial dysmorphic } \\
\text { features, mild Coarse face }\end{array}$ & $\mathrm{DS}, \mathrm{HS}$ & $\mathrm{N}$ & MIAI & $\mathrm{P}$ \\
\hline 7 & MSP II & M & - & $\begin{array}{l}\text { dysostosis multiplex, } \\
\text { Skeletal deformity; } \\
\text { Hepatospelnomegaly, } \\
\text { joint; stiffness; } \\
\text { dolichocephaly, claw, } \\
\text { hand }\end{array}$ & $\begin{array}{l}\text { Carpal tunnel, large } \\
\text { tongue, Hydrocephaly, } \\
\text { repeated diarrhea, large; } \\
\text { tongue, J-shape sella; } \\
\text { turcica }\end{array}$ & $\begin{array}{l}\text { Coarse face, clear cornea, } \\
\text { hypertelorism }\end{array}$ & $\mathrm{DS}, \mathrm{HS}$ & + & $\begin{array}{l}\text { Cardiomyopathy, } \\
\text { Valvulopathy }\end{array}$ & BT \\
\hline 8 & MSP II & M & - & $\mathrm{AF}$ & $\#$ & $\#$ & $\#$ & $\#$ & $\#$ & $\#$ \\
\hline 9 & MSP IIIB & M & + & $\begin{array}{l}\text { Mild speech difficulty, } \\
\text { insomnia, mild Skeletal } \\
\text { deformity, }\end{array}$ & $\begin{array}{l}\text { Psychotic, ADHD, NDR, } \\
\text { hairsotysm, mild speech } \\
\text { difficulty }\end{array}$ & Moderate Coarse face & HDCS & + & $\mathrm{N}$ & $\mathrm{N}$ \\
\hline 10 & MSP IIIB & $\mathrm{F}$ & + & mild Skeletal deformity, & Difficult mood & Coarse face & ND & + & Valvulopathy & $\mathrm{N}$ \\
\hline 11 & MSP IIIA & F & + & Mild speech difficulty & Aggressive behavior & Mild coarse face & $\mathrm{HSCS}$ & + & $\mathrm{N}$ & MILD BT \\
\hline 12 & MSP IIIB & M & + & $\begin{array}{l}\text { insomnia, mild Skeletal } \\
\text { deformity, }\end{array}$ & ADHD, hairsotysm & Hair sot face & HS & + & $\mathrm{N}$ & $\mathrm{N}$ \\
\hline 13 & MSP IIIB & F & + & $\begin{array}{l}\text { moderate speech } \\
\text { difficulty, mild short } \\
\text { stature, Seizure, }\end{array}$ & Hairsotysm, NDR, otitis & Mild coarse face & HS & Mild + & $\mathrm{N}$ & $\mathrm{N}$ \\
\hline 14 & MSP IIIA & M & + & $\begin{array}{l}\text { Seizure, mild short } \\
\text { stature }\end{array}$ & $\begin{array}{l}\text { Claw hand, NDD, } \\
\text { recurrent media otitis }\end{array}$ & MPS like phenotype & HS DSCS & + & Cardiomyopathy & Mixed \\
\hline 15 & MSP IIIB & M & + & $\begin{array}{l}\text { Mild speech difficulty, } \\
\text { insomnia }\end{array}$ & ADHD, NDR, & Mild coarse face & $\mathrm{HS}, \mathrm{CS}$ & + & $\mathrm{N}$ & $\mathrm{N}$ \\
\hline 16 & MSP IIIA & M & + & $\begin{array}{l}\text { Otitis media, speech } \\
\text { difficulty, }\end{array}$ & $\begin{array}{l}\text { NDD, NDR, Claw, hand, } \\
\text { Psychotic }\end{array}$ & coarse face & Hs cs & + & $\mathrm{N}$ & Mixed \\
\hline 17 & MSP IIIA & M & + & Seizure, Speech delay & Claw hand, Hairsotysm & Mild coarse face & ND & + & Valvulopathy & MILD BT \\
\hline 18 & MSP IIIA & F & + & mild Skeletal deformity & NDR, Aggressive behavior & MPS like phenotype & HSCS & + & $\mathrm{N}$ & $\mathrm{N}$ \\
\hline 19 & MSP IIIA & $\mathrm{F}$ & + & $\begin{array}{l}\text { Insomnia, Skeletal } \\
\text { deformity, }\end{array}$ & ADHD, Psychotic & coarse face & ND & Mild + & CHD & Mixed \\
\hline
\end{tabular}

from unrelated Iranian families, manifesting various biochemical and clinical characteristics of MPS disease. Additionally, MPS is promptly diagnosed through urine and blood biochemical analysis $(8,11)$. However, a definite diagnosis of different types of MPS requires a wide range of comprehensive biochemical and molecular genetic techniques (12). In this study, to evaluate mutations of IDUA, IDS, SGSH, and NAGLU genes, we sequenced 19 blood samples acquired from MPS patients using a Sanger sequencing method. In our study, 15 variants in these genes were reported in MPS patients, of which eight variants were novel. Out of 15 variants, 9 variants were disease-causing mutations. Of the changes in IDUA identified in this study, the novel change c.99T $>\mathrm{C}$ (p.H33H) was found in one patient, which was a disease causing one, and it had not been published previously. However, the other variant c.1205G $>$ A (p.W402*) was disease causing, and it had been reported by Zanetti et al. in Italian population (13) and Atceken et al. in
Turkish population (14). The IDUA gene contains 14 exons (15). It should be noted that in our study, $80 \%$ of IDUA mutations were found in exon 1, and only $10 \%$ were in exon 9. Chkioua et al. showed novel splice site mutation in intron 11 of IDUA gene in four MPS I patients from four families from northern Tunisia (16). Sánchez reported that $14 \%$ of the IDUA gene mutations in his 7-member population were in exons 5 and 9 (17). Chkioua et al. reported that exon 1 mutations were detected in $75 \%$ of the patients, and exon 9 mutations were detected in $25 \%$ of patients in eight families with MPS I (18). Therefore, our results are consistent with those of Chkioua et al. The novel nonsense change c.514C $>$ T (p.R172*) in exon 5 of IDS gene was found in more than one patient (in $10 \%$ our sample size). This variant was predicted as disease causing. Chistiakov et al. analyzed 17 children with hunter syndrome and found exon 5 of IDS gene mutations in $27 \%$ of mutations (19).

Exon 5 of IDS gene mutation accounted for only $5.5 \%$ of 


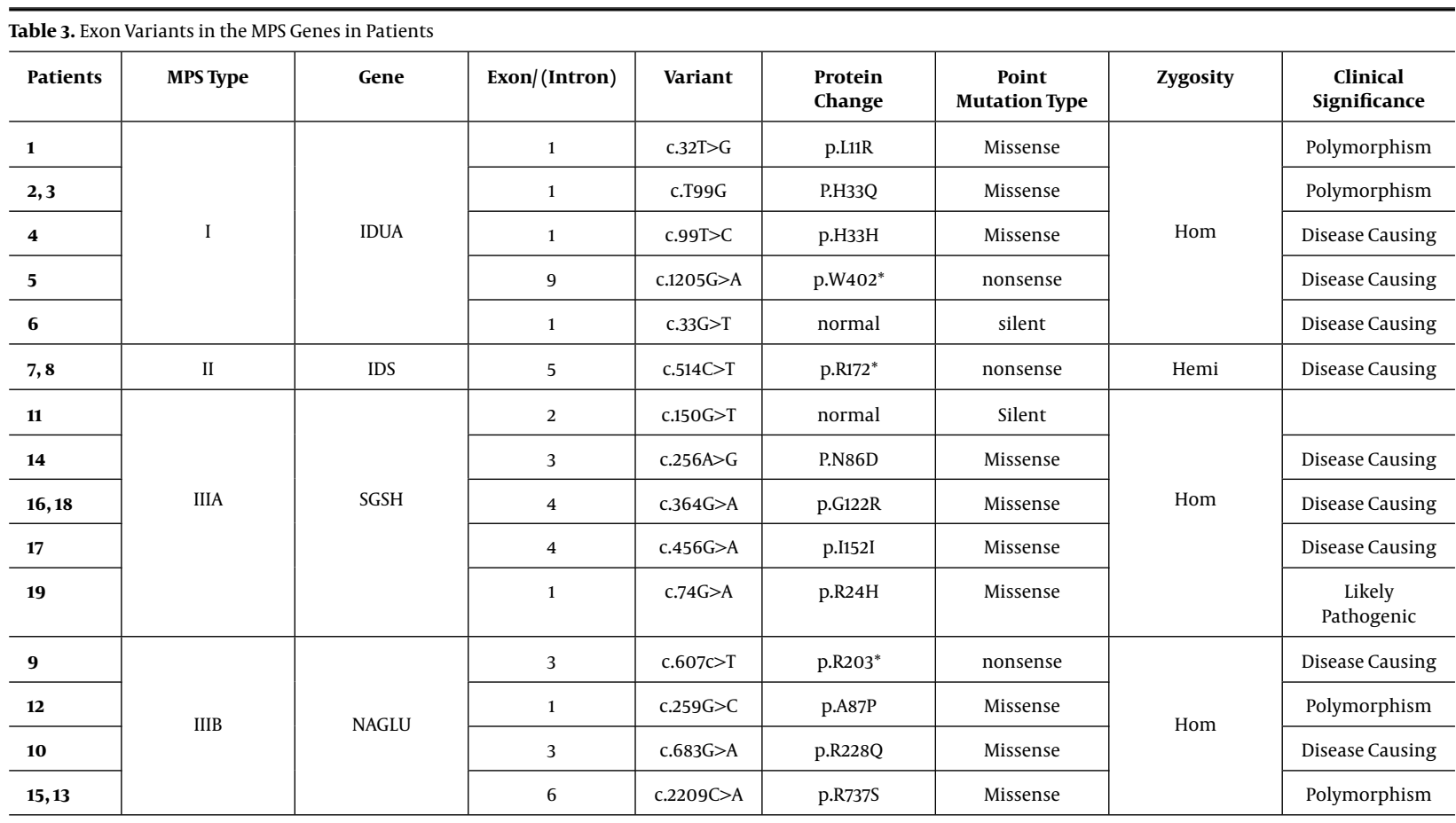

the total mutations observed in the study by Zhang (20). SGSH gene contains 8 exons, and interestingly, all the novel mutations in this study were found in exons 1 to 4 . Mutational analysis on 23 patients from the UK with Sanfilippo syndrome type A showed that $30 \%$ of total mutations were located in exons 1 to 4 (21).

Yassaee et al. showed that SGSH mutations were in exons 2 and 7 in 11 families (22). Of the 5 variants found in the SGSH gene, three variants (c.364G >A (p.G122R), c.456G $>A$ (p. p.I152I), and c.74G>A (p. p.R24H)) were predicted as disease causing, and the last two variants were not reported in any population; however, c.364G $>$ A had been published in 2000 by Beesley et al. (21). In the study of NAGLU gene variants, three variants including (c.607c $>T$ (p.R203*), c.259G >C (p.A87P), and c.683G >A (p.R228Q)) were predicted as novel pathogenic variants. In addition, Yassaee et al. revealed that NAGLU mutations were located in exons 2, 5, and 6 (22); but our data demonstrated that NAGLU mutations were in exons 1,3 , and 6 . Similar studies have been performed in different countries. For example, Bekri's study described the clinical and molecular features of 13 Algerian MPS 1 patients by molecular study of the IDUA gene (23).

Moreover, in a study conducted in 2014, molecular studies were performed in seven Mexican MPS I patients, and p.W402X was listed as a common mutation (17). Vafiadaki et al. identified the primary genetic lesion in 57 unrelated Korean MPS II patients, and they found various types of mutation in 42 patients (24). In the study by Beesley et al., mutational analysis was performed on the sulphamidase gene from 23 patients in the UK. In the study by Beesley et al., mutational analysis was performed on the sulphamidase gene from 23 patients in the UK, and 13 different new mutations were found (21). Our results showed positive mutation spectrum of IDUA, IDS, SGSH, and NAGLU genes in the Iranian cohort. The high fraction of detected novel variants highlights the mentioned genes mutation heterogeneity. However, this heterogeneity generates challenges in the interpretation of genotype and phenotype correlation. Meanwhile, if these mutations are studied and proven in a larger sample population, they could help to identify and categorize the patients with MPS symptoms. Due to the MPS heterogeneity and the clinical picture complexity, whole exome sequencing (WES) is usually recommended to all clients as a first tire test in Iran, which is a time consuming and costly test. If we have Iranian common mutations in the mentioned exons of target genes, we can screen the patients with MPS symptoms and diagnose them earlier at a lower cost.

\section{Acknowledgments}

We gratefully thank all family members and affected individuals who participated in this study. This article is extract of PhD student project. This research was supported by the National Institute of Genetic Engineering 
and Biotechnology (Approval No. IR.NIGEB.EC.1397.8.23.C), Tehran, Iran.

\section{Footnotes}

Authors' Contribution: Study concept and design: M. Houshmand \& S. Farshidi \& S. Saberi; Analysis and interpretation of data: S. Saberi \& R. Jazayeri \& B. Kamalidehghan \& M. Houshmand; Drafting of the manuscript: R. Jazayeri; Critical revision of the manuscript for important intellectual content: R. Jazayeri \& M. Houshmand.

Conflict of Interests: There was no conflict of interest.

Ethical Approval: The present study was approved by the Ethical Committee of NIGEB (Approval No. IR.NIGEB.EC.1397.8.23.C), Tehran, Iran

Funding/Support: This article is part of a Ph.D. thesis that was financially supported by the National Institute of Genetic Engineering and Biotechnology (Approval No. IR.NIGEB.EC.1397.8.23.C), Tehran, Iran.

Informed Consent: An informed consent was obtained from all patients.

\section{References}

1. Giugliani R, Federhen A, Rojas MV, Vieira T, Artigalas O, Pinto LL, et al. Mucopolysaccharidosis I, II, and VI: Brief review and guidelines for treatment. Genet Mol Biol. 2010;33(4):589-604. doi: 10.1590/S1415-47572010005000093. [PubMed: 21637564]. [PubMed Central: PMC3036139].

2. Clarke LA. The mucopolysaccharidoses: a success of molecular medicine. Expert Rev Mol Med. 2008;10. e1. doi: 10.1017/S1462399408000550. [PubMed: 18201392].

3. Muenzer J. Overview of the mucopolysaccharidoses. Rheumatology (Oxford). 2011;50 Suppl 5:v4-12. doi: 10.1093/rheumatology/ker394. [PubMed: 22210669].

4. Jones S, Wynn R, Patterson MC. Mucopolysaccharidoses: Treatment UpToDate [Database]. Wolters Kluwer. 2017.

5. Kumar P, Henikoff S, Ng PC. Predicting the effects of coding nonsynonymous variants on protein function using the SIFT algorithm. Nat Protoc. 2009;4(7):1073-81. doi: 10.1038/nprot.2009.86. [PubMed 19561590].

6. Adzhubei IA, Schmidt S, Peshkin L, Ramensky VE, Gerasimova A, Bork $\mathrm{P}$, et al. A method and server for predicting damaging missense mutations. Nat Methods. 2010;7(4):248-9. doi: 10.1038/nmeth0410-248. [PubMed: 20354512]. [PubMed Central: PMC2855889].

7. Cleary MA, Wraith JE. The presenting features of mucopolysaccharidosis type IH (Hurler syndrome). Acta Paediatr. 1995;84(3):337-9. doi: 10.1111/j.1651-2227.1995.tb13640.x. [PubMed: 7780260].

8. Tomatsu S, Fujii T, Fukushi M, Oguma T, Shimada T, Maeda M, et al. Newborn screening and diagnosis of mucopolysaccharidoses. $\mathrm{Mol}$ Genet Metab. 2013;110(1-2):42-53. doi: 10.1016/j.ymgme.2013.06.007. [PubMed: 23860310]. [PubMed Central: PMC4047214].

9. Chkioua L, Aloui C, Laradi S, Grissa O, Turkia HB, Ouesleti S, et al. Genetic heterogeneity of 72 patients with mucopolysaccharidosis in Tunisia. Int J New Technol. 2015;1(3).
10. Valstar MJ, Bruggenwirth HT, Olmer R, Wevers RA, Verheijen FW, Poorthuis BJ, et al. Mucopolysaccharidosis type IIIB may predominantly present with an attenuated clinical phenotype. $J$ Inherit Metab Dis. 2010;33(6):759-67. doi: 10.1007/s10545-010-9199-y. [PubMed: 20852935]. [PubMed Central: PMC2992652].

11. Leistner S, Giugliani R. A useful routine for biochemical detection and diagnosis of mucopolysaccharidoses. Genet Mol Biol. 1998;21(1):163-7. doi: $10.1590 /$ s1415-47571998000100028.

12. Emre S, Terzioglu M, Coskun T, Tokath A, Ozalp I, Muller V, et al. Biochemical and molecular analysis of mucopolysaccharidoses in Turkey. Turk J Pediatr. 2002;44(1):13-7. [PubMed: 11858372].

13. Zanetti A, D'Avanzo F, Rigon L, Rampazzo A, Concolino D, Barone $\mathrm{R}$, et al. Molecular diagnosis of patients affected by mucopolysaccharidosis: a multicenter study. Eur J Pediatr. 2019;178(5):739-53. doi: 10.1007/s00431-019-03341-8. [PubMed: 30809705]. [PubMed Central: PMC6459791].

14. Atceken N, Ozgul RK, Yucel Yilmaz D, Tokatli A, Coskun T, Sivri HS, et al. Evaluation and identification of IDUA gene mutations in Turkishpatients with mucopolysaccharidosis type I. Turk J Med Sci. 2016;46(2):404-8. doi: 10.3906/sag-1411-160. [PubMed: 27511503].

15. Menon KP, Tieu PT, Neufeld EF. Architecture of the canine IDUA gene and mutation underlying canine mucopolysaccharidosis I. Genomics. 1992;14(3):763-8. doi: 10.1016/s0888-7543(05)80182-x. [PubMed: 1339393].

16. Chkioua L, Boudabous H, Jaballi I, Grissa O, Turkia HB, Tebib N, et al. Novel splice site IDUA gene mutation in Tunisian pedigrees with hurler syndrome. Diagn Pathol. 2018;13(1). doi: 10.1186/s13000-0180710-3.

17. Sánchez Suárez AL, Sánchez Suárez LM. [Genetic mutations and the relationship with clinical phenotype in patients with mucopolysaccharidosis type I in northeast Mexico]. Gac Med Mex. 2014;150(4):289-96. Spanish. [PubMed: 25098213].

18. Chkioua L, Khedhiri S, Kassab A, Bibi A, Ferchichi S, Froissart R, et al. Molecular analysis of mucopolysaccharidosis type I in Tunisia: identification of novel mutation and eight Novel polymorphisms. Diagn Pathol. 2011;6(1). doi: 10.1186/1746-1596-6-39.

19. Chistiakov DA, Kuzenkova LM, Savost'anov KV, Gevorkyan AK, Pushkov AA, Nikitin AG, et al. Genetic analysis of 17 children with Hunter syndrome: identification and functional characterization of four novel mutations in the iduronate-2-sulfatase gene. J Genet Genomics. 2014;41(4):197-203. doi: 10.1016/j.jgg.2014.01.007. [PubMed: 24780617].

20. Zhang H, Li J, Zhang X, Wang Y, Qiu W, Ye J, et al. Analysis of the IDS gene in 38 patients with Hunter syndrome: the c.879G $>$ A (p.Gln293Gln) synonymous variation in a female create exonic splicing. PLoS One. 2011;6(8). e22951. doi: 10.1371/journal.pone.0022951. [PubMed: 21829674]. [PubMed Central: PMC3150403].

21. Beesley CE, Young EP, Vellodi A, Winchester BG. Mutational analysis of Sanfilippo syndrome type A (MPS IIIA): identification of 13 novel mutations. J Med Genet. 2000;37(9):704-7. doi: 10.1136/jmg.37.9.704. [PubMed: 11182930]. [PubMed Central: PMC1734705].

22. Yassaee VR, Hashemi-Gorji F, Miryounesi M, Rezayi A, Ravesh Z, Yassaee $\mathrm{F}$, et al. Clinical, biochemical and molecular features of Iranian families with mucopolysaccharidosis: A case series. Clinica Chimica Acta. 2017;474:88-95. doi: 10.1016/j.cca.2017.08.017.

23. Tebani A, Zanoutene-Cheriet L, Adjtoutah Z, Abily-Donval L, BrasseLagnel C, Laquerriere A, et al. Clinical and molecular characterization of patients with mucopolysaccharidosis type I in an Algerian series. Int J Mol Sci. 2016;17(5). doi: 10.3390/ijms17050743. [PubMed: 27196898]. [PubMed Central: PMC4881565].

24. Vafiadaki E, Cooper A, Heptinstall LE, Hatton CE, Thornley M, Wraith JE. Mutation analysis in 57 unrelated patients with MPS II (Hunter's disease). Arch Dis Child. 1998;79(3):237-41. doi: 10.1136/adc.79.3.237. [PubMed: 9875019]. [PubMed Central: PMC1717680]. 
Table 2. Primer Sequences for IDUA, IDS, SGSH, and NAGLU genes

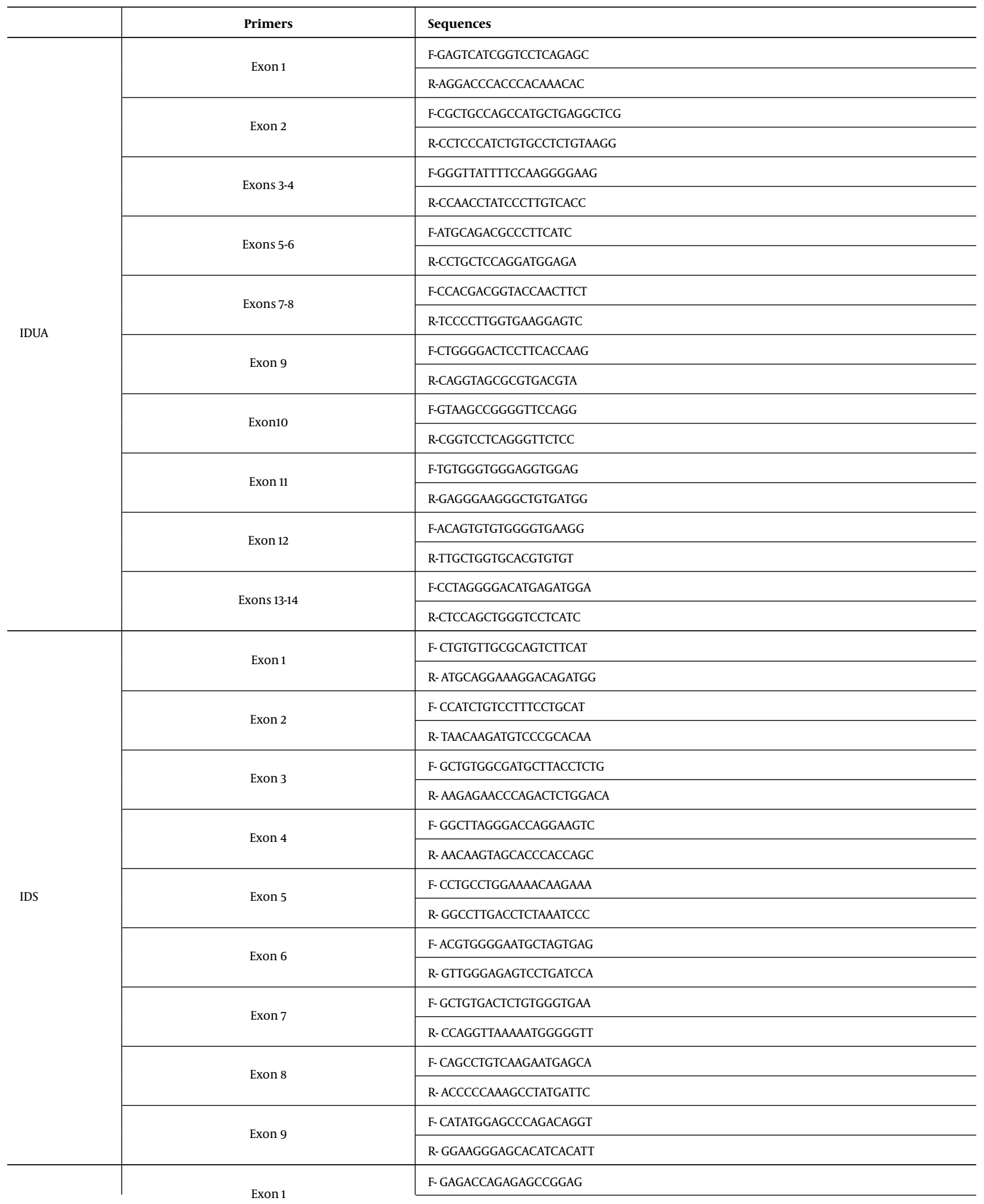




\begin{tabular}{|c|c|c|}
\hline & & R-ATTGACCACGGGTGGGG \\
\hline & Fyon 2 & F- CTCACTCCCAGTGCTGTTTC \\
\hline & & R-GGGAGACGTGGCAGAGG \\
\hline & Fyon-2 & F- GAGAACAGGTGCGGCAG \\
\hline & & R-ACCTCCTGGGCTCTGGC \\
\hline & Fxon 4 & F-GAAGGGAGCAGAAAGGGTTG \\
\hline & & R-ATCCCGCCGGAAGACTC \\
\hline & 5 & F- CCGAGGGGCTTCCTGTG \\
\hline & & R- CAAGCTCGTAGGAGGCCAG \\
\hline & Fvon & F- GTTCTGGGCTAACCCATTTG \\
\hline & & R- GACCCTCACCCACATTATGC \\
\hline & Fyon 7 & F- GTCTACACACACCACCCGC \\
\hline & & R- CCCGTCCCAGATCCACTC \\
\hline & Frones & F- GAGGGCAGCTCCTGTGTG \\
\hline & & R- CATCTCCAGAAGCTGAGCAA \\
\hline & Гуоро & F- CTGGTACAAGGACCTCCGTC \\
\hline & & R-AAGGACAACTGTGTCCCCTG \\
\hline \multirow{20}{*}{ NAGLU } & \multirow{2}{*}{ Exon 1a } & F- CCCAAGGGAGTATCCTGGTA \\
\hline & & R-TGGCAGCCACAGAAGTCG \\
\hline & \multirow{2}{*}{ Exon $1 b$} & F- CTTGGACACCTACAGCCTGG \\
\hline & & R-AGGCTCTGAAAGGCAGAGTG \\
\hline & \multirow{2}{*}{ Exon 2} & F- GGTACCTGGTCTCAGCTCCA \\
\hline & & R-GAAAACACCTACGGTGGCTC \\
\hline & \multirow{2}{*}{ Exon 3} & F-CCAGCACAAAGAAGCAATGA \\
\hline & & R-ATCTATCACCGATTCTGCCC \\
\hline & \multirow{2}{*}{ Exon 4} & F- CTGCGTGTATCCTGGGAGAT \\
\hline & & R-GGAATAAAATTCCCTCTCTGAGC \\
\hline & \multirow{2}{*}{ Exon 5} & F- GTGAACACTATGGCGGCTTC \\
\hline & & R- GTCCCTCTGCCTACCCCTAC \\
\hline & \multirow{2}{*}{ Exon 6a } & F- GCCCTCTGTTTCATCACTCC \\
\hline & & R-GGTGGGAGACCCCATACC \\
\hline & \multirow{2}{*}{ Exon $6 \mathrm{~b}$} & F- TGGTCTATTCCCTCATGGCT \\
\hline & & R- GTCACTAGCCAGCACCTCGT \\
\hline & \multirow{2}{*}{ Exon $6 \mathrm{c}$} & F- CTATGAGGAGGCAAGAAGCG \\
\hline & & R-AGCGGGGGTAATATTTGAGG \\
\hline & \multirow{2}{*}{ Exon 6d } & F- CGTTCTCAGCAAGCAGAGGT \\
\hline & & R-TATAGCCCTGAGTCCTCCCA \\
\hline
\end{tabular}

